\title{
Communications
}

\section{Electrochemical Reduction of Zinc Phosphate}

\author{
Chang Hwan Kim, Junghyun Lee, and Woonsup Shin* \\ Department of Chemistry and Interdisciplinary Program of Integrated Biotechnology, \\ Inorganic and Bio-Materials Center of BK21, Sogang University, Seoul 121-742, Korea. ${ }^{*}$ E-mail: shinws@sogang.ac.kr \\ Received December 29, 2009, Accepted January 16, 2010
}

Key Words: Rechargeable battery, Zinc phosphate

In lead-acid battery, the electrochemical redox reaction of $\mathrm{Pb}_{(\mathrm{s})} / \mathrm{PbSO}_{4(\mathrm{~s})}$ is used by reducing $\mathrm{Pb}(\mathrm{II})$ and oxidizing $\mathrm{Pb}(0)$ in sulfate rich solution. Since both reduced form and oxidized form are insoluble, they cannot diffuse to the opposite electrodes and react. It is a very common strategy to make a stable battery electrode that a metal element is reduced and oxidized in solution containing an abundance of anion readily precipitating with the metal ion. ${ }^{1}$ For the application of this strategy to construction of rechargeable battery using bio-compatible electrode materials and electrolytes, the use of phosphate ion can be considered as anion readily precipitating with metal ions. If phosphate buffer with neutral $\mathrm{pH}$ is used as electrolyte, the better bio-compatibility will be achieved than most of rechargeable battery using strong acid, strong base or organic solvent as electrolyte solution. There are many metal ions readily precipitating with phosphate ion, and zinc is one of them.

Zinc is non-toxic, abundant, relatively inexpensive, and has very negative electrode potential, high hydrogen overpotential and it has been used as electrode material for a long time since the Leclanche battery. ${ }^{2}$ Although $\mathrm{Zn}$ anode has been mostly used in primary batteries, recently, there are a lot of efforts to use zinc as a rechargeable negative electrode material. Examples are zinc-silver, ${ }^{3}$ zinc-nickel, ${ }^{4}$ zinc-air ${ }^{5}$ batteries and some of them are already commercialized. However, in all of above examples strong alkaline solution is used as an electrolyte solution. Rechargeable $\mathrm{Zn}$ batteries which do not use strong alkaline electrolyte were also reported, however, $\mathrm{Zn} / \mathrm{Br}_{2}$ flow cell ${ }^{6}$ cannot be considered as human friendly, $\mathrm{Zn} /$ polymer batteries $^{7-9}$ and $\mathrm{Zn} / \mathrm{ZnSO}_{4} / \mathrm{MnO}_{2}$ battery ${ }^{10}$ use somewhat acidic electrolyte solutions and show poor recyclability. To test the possibility of constructing rechargeable battery using zinc electrode operable in neutral phosphate buffer solution, the electrochemical reduction of zinc phosphate and its re-oxidation was investigated.

$30 \mathrm{mg}$ of zinc phosphate, $\mathrm{Zn}_{3}\left(\mathrm{PO}_{4}\right)_{2} \cdot 4 \mathrm{H}_{2} \mathrm{O}$ (High Purity Chemicals Laboratory Co. Ltd., Japan) and $15 \mathrm{mg}$ of acetylene black were dispersed in $1 \mathrm{~mL}$ of isopropyl alcohol containing $0.5 \%$ Nafion $^{\circledR}$. A zinc phosphate electrode was prepared by drop-coating $5 \mu \mathrm{L}$ of the dispersion on a $5 \mathrm{~mm}$ diameter printed carbon electrode, (SE100, Zensor R\&D, Taiwan) (PCE) and drying at ambient temperature. The negative electrode was voltammetrically characterized in a three-electrode cell with a
$\mathrm{Ag} / \mathrm{AgCl}(3 \mathrm{M} \mathrm{KCl})$ reference electrode and a Pt counter electrode, using a $\mathrm{CHI} 440$ a potentiostat (Austin, TX, USA). A WBCS 3000 automatic battery cycler (Wonatech Co. Ltd., Seo$\mathrm{ul}$, Korea) was used for the cycling and the associated measurements. A pH 7 phosphate buffer was prepared by adding $\mathrm{KOH}$ to $20 \mathrm{mM} \mathrm{KH}_{2} \mathrm{PO}_{4}$.

Figure la shows voltammograms of zinc phosphate electrode in $\mathrm{pH} 7$ phosphate buffer, recorded with the scan rate of $1 \mathrm{mV} / \mathrm{s}$. Line crossing observed in the reduction features of 1 st cycle (solid line) and 15th cycle (dotted line) indicates the deposition of metallic zinc. The oxidation of metallic zinc in phosphate rich solution to form zinc phosphate can be expressed as equation (1).

$$
\mathrm{Zn}_{3}\left(\mathrm{PO}_{4}\right)_{2} \cdot 4 \mathrm{H}_{2} \mathrm{O}_{(\mathrm{s})}+6 \mathrm{e}^{-} \leftrightarrows 3 \mathrm{Zn}_{(\mathrm{s})}+2 \mathrm{PO}_{4}^{3^{3-}(\mathrm{aq})}+4 \mathrm{H}_{2} \mathrm{O}_{(\mathrm{l})}
$$

The standard electrode potential of the electrochemical reaction (1) could be calculated from the electrode potential of $\mathrm{Zn} / \mathrm{Zn}^{2+}\left(\mathrm{E}^{\mathrm{o}}=-0.762 \mathrm{~V} v\right.$ s. NHE$)$ and the solubility product of zinc phosphate $\left(\mathrm{K}_{\mathrm{sp}}=5 \times 10^{-36}\right)$ using formula $(2)$ and the value was calculated to be $-1.110 \mathrm{~V} v s$. NHE.

$$
\Delta \mathrm{E}^{\mathrm{o}}=(\mathrm{RT} / \mathrm{nF}) \ln \mathrm{K}
$$

Since $\left[\mathrm{PO}_{4}^{3-}\right]$ in pH 7, $20 \mathrm{mM}$ phosphate buffer is $5.5 \times 10^{-8} \mathrm{M}$, by substitution of this value to Nernst equaton, the electrode potential of $\mathrm{Zn} / \mathrm{Zn}_{3}\left(\mathrm{PO}_{4}\right)_{2}$ in $\mathrm{pH}$ 7, $20 \mathrm{mM}$ phosphate buffer was calculated to be $-0.967 \mathrm{~V}$ vs. NHE, that is, $-1.167 \mathrm{~V}$ vs. Ag/ $\mathrm{AgCl}$. This value shows good agreement with the anodic peak potential of the cyclic voltammograms shown in Figure 1a. Anodic peak current increased for first 15 cycles then decreased reaching practically nil at 100 th cycle. The increase of the anodic peak current in the initial 15 cycles is similar to that seen in alkaline and acidic electrolyte rechargeable batteries using $\mathrm{Zn}$ as negative electrode, due to the compositional and morphological changes in the $\mathrm{Zn}$ material. ${ }^{11,12}$ The decrease of the anodic peak current in cycles after 15 th cycle of cyclic voltammogram (Figure 1a) is practically same phenomena to the decrease of unit discharge capacity in charge-discharge experiment (Figure 1b). Figure $1 \mathrm{~b}$ shows the unit discharge capacity of the zinc phosphate electrode as a function of the cycle number when 
(a)

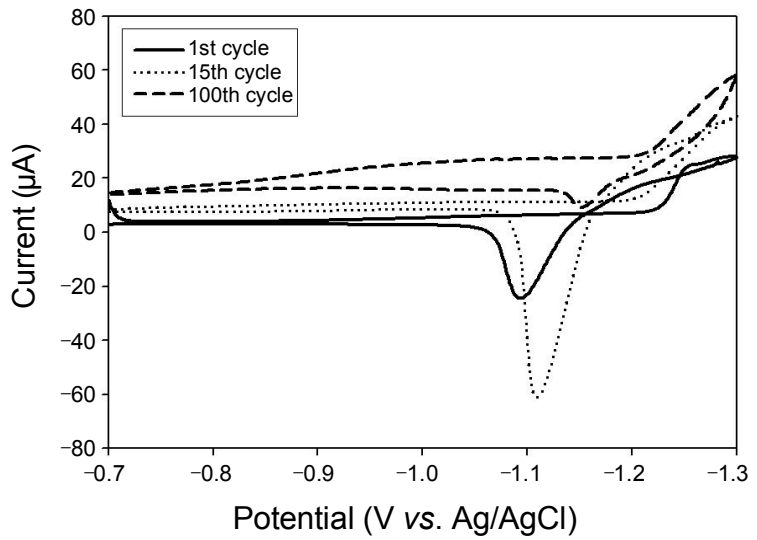

(b)

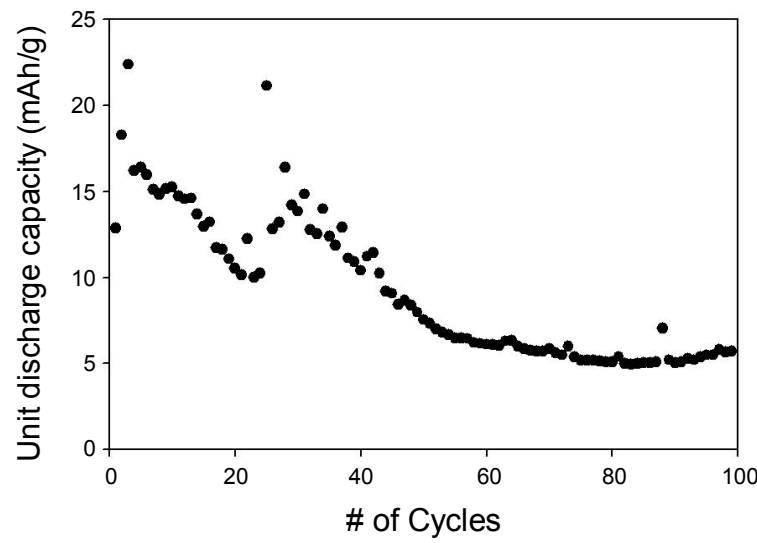

Figure 1. (a) 1 st cycle (solid line), 15th cycle (dotted line) and 100th cycle (dashed line) of cyclic voltammogram and (b) unit discharge capacity of zinc phosphate electrode in $\mathrm{pH}$ 7, $20 \mathrm{mM}$ phosphate buffer.

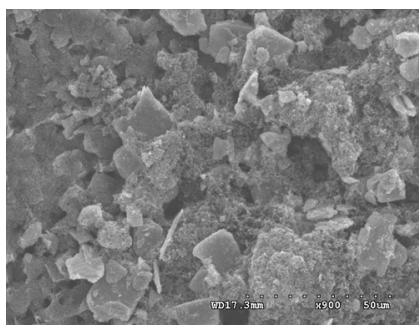

(a)

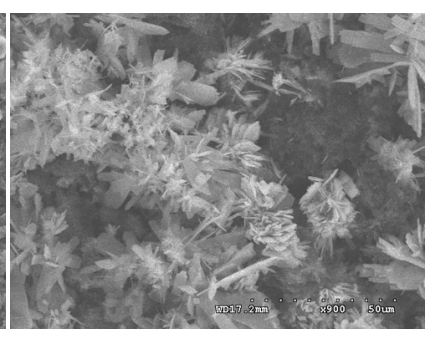

(b)
Figure 2. Scanning electron micrographs of zinc phosphate electrode (a) as prepared and (b) after 100 cycles of charge-discharge in $\mathrm{pH} 7$, $20 \mathrm{mM}$ phosphate buffer.

charged for $10 \mathrm{~min}$ at $255 \mu \mathrm{A} / \mathrm{cm}^{2}$ then discharged at the same current density until the potential reached to $-0.5 \mathrm{Vvs}$. $\mathrm{Ag} / \mathrm{AgCl}$. The slight increase and decrease in the unit charge capacity in $\sim 30$ cycles (Figures 1b) can be attributed to morphological changes in the $\mathrm{Zn}$ containing solids upon redox reactions. The phenomenon is a little different from the one occurs in alkaline and acidic electrolyte rechargeable $\mathrm{Zn}$-anode batteries where the capacity increases at initial cycles and decreases and stabilizes. ${ }^{13,14}$ The capacity value, about $15 \mathrm{mAh} / \mathrm{g}$ at initial cycles, is too small compared to that of known rechargeable alkaline $\mathrm{Zn}$ electrodes, typically $100 \sim 250 \mathrm{mAh} / \mathrm{g} .{ }^{15}$ Since the current $\mathrm{Zn}$ phosphate electrode uses fully bio-compatible materials and electrolyte, it has advantage in usage of powering biomedical devices. The capacity and cyclability could be improved by future research including the optimization of solution condition and the methods of electrode preparation and the construction of full cell. Figure 2 shows SEM images of zinc phosphate electrode as prepared (Figure 2a) and after 100 cycles of chargedischarge in phosphate buffer (Figure 2b). The morphology change induced by the formation of new crystal structures, are clearly seen. The decrease in unit discharge capacity upon cycling might be explained by the growth of crystal structure shown in Figure 2b; Initially zinc phosphate electrically connected to the electrode reduced to metallic zinc and then re-oxidized to zinc phosphate forming the new crystal structure, where most part of newly formed zinc phosphate lost their electric contact to the electrode. Consequently, the continual decrease of the amount of electrically connected $\mathrm{Zn}$ atoms caused the decrease of unit discharge capacity.

In conclusion, we demonstrated first that the electrochemical reduction of zinc phosphate in neutral phosphate buffer is possible and potentially applicable to bio-compatible rechargeable battery. The actual redox component is $\mathrm{Zn}(\mathrm{s}) / \mathrm{Zn}$ phosphate(s) and the future research about the control of crystal formation for the better cyclability is required.

Acknowledgments. This research was supported by the Converging Research Center Program (2009-0082069) and the Nano/Bio Science \& Technology Program (M1053609000105N3609-00110) through the National Research Foundation of Korea (NRF) funded by the Ministry of Education, Science and Technology, the Human Resource Training Project for Strategic Technology of the Ministry of Knowledge Economy (MKE) and Korea Industrial Technology Foundation (KOTEF) of the Korean government, and MOEHRD (Basic Research Promotion Fund) (KRF-2008-314-C000235).

\section{References}

1. Kiehne, H. A., Ed.; Battery Technology Handbook; Marcel Dekker Inc.: New York and Basel, 2003.

2. Zhang, X. G. Corrosion and Electrochemistry of Zinc; Plenum Press: New York and London, 1996; Ch. 14.

3. Karpinski, A. P.; Makovetski, B.; Russel, S. J.; Serenyi, J. R.; Williams, D. C. J. Power Sources 1999, 80, 53.

4. Jones, R. A. U. S. Patent No. 43585171982.

5. Jacquelin, J. U. S. Patent No. 40384581977.

6. Zito, R. Jr. U. S. Patent No. 33821021968.

7. Rahmanifar, M. S.; Mousavi, M. F.; Shamsipur, M. J. J. Power Sources 2002, 110, 229.

8. Saraswathi, R.; Gerard, M.; Malhotra, B. D. J. Appl. Polym. Sci. 1999, 74, 145.

9. Grgur, B. N.; Gvozdenovic, M. M.; Stevanovic, J.; Jugovic, B. Z.; Marinovic, V. M. Electrochim. Acta 2008, 53, 4627.

10. Yamamoto, T.; Shoji, T. Inorg. Chim. Acta 1986, 117, L27.

11. Zhu, X. J.; Guo, Z. P.; Zhang, P.; Du, G. D.; Zeng, R.; Chen, Z. X.; Li, S.; Liu, H. K. J. Mater. Chem. 2009, 19, 8360.

12. Wei, Y. J.; Ehrenberg, H.; Bramnik, N. N.; Nikolowski, K.; Baehtz, C.; Fuess, H. Solid State Ionics 2007, 178, 253.

13. Karpinski, A. P.; Makovetski, B.; Russell, S. J.; Serenyi, J. R.; Williams, D. C. J. Power Sources 1999, 80, 53.

14. Grgur B. N.; Gvozdenovic, M. M.; Stevanovic, J.; Jugovic, B. Z.; Marinovic, V. M. Electrochim. Acta 2008, 53, 4627.

15. Köhler, U.; Antonius, C.; Bäuerlain, P. J. Power Sources 2004, 127,45 . 